\title{
The Influence of Entrepreneur Competencies and Business Ethics on Growth Business (Case Study Local Food In Sumatera)
}

\author{
Yulinda \\ Dept. Of Management \\ Faculty Economy And Business \\ University of Sumatera Utara \\ Medan, Indonesia \\ yulindamuchtar59@gmail.com
}

\author{
Syafrizal Helmi Situmorang \\ Dept. Of Management \\ Faculty Economy And Business \\ University of Sumatera Utara \\ Medan, Indonesia \\ shelmi09@gmail.com
}

\author{
Sitti Raha A. Salim \\ Dept. Of Management \\ Faculty Economy And Business \\ University of Sumatera Utara \\ Medan, Indonesia \\ sittisalim@yahoo.com
}

\begin{abstract}
The most important challenges that entrepreneurs face is growth business. Growth creates opportunities for entrepreneurs to expand their business, attract more consumers and talents Considering growth opportunities, entrepreneurs must have competencies and business ethics to improve their business. This study examines influence competencies and business ethics to growth business. The research population consists of entrepreneurs who have shopped for retail unique product atlocalfood in Medan, Aceh, Padang and Palembang. Sample size 66 respondents by using the purposive sampling. The data were analyzed through multivariate analysis. Finding from research that many entrepreneur didn't inform their packaging of products such as the composition of the product the expiration date, permits the production, halal label. The other findings indicates that entrepreneurs most improve their financial competencies. The results showed that there is a positive and significant influence between competence and business ethics towards enterprise development.
\end{abstract}

Keywords-:competencies, Business ethics,business development,local food

\section{INTRODUCTION}

Indonesia is a country that has many potential tourist destinations. The demand is not only foreign tourists, but also local tourists from indonesia. Data from the Ministry of Tourism and Creative Economy (Kemenparekraf) shows the number oflocal touris travel continues to increase.Increasing the number of local tourists travel will bring a positive impact for the domestic tourism industry. The effect is not just to increase the income of the state, but the business actors engaged in tourism.In addition to handicraft objects, other products that are also targeted by local tourists are local typical of the region. The high demand makes local typical of the area into a lucrative business opportunity. No wonder, shops that sell local in some major cities are becoming popular tourist destinations. Each region also has a special gift.
Local are a typical food designation of an area. Souvenir food should have existed for a long time, passed down from generation to generation and has a history. The development of technology and social media marketing to make food business local typical of the increasingly famous. Now, local are no longer a typical food and are made from traditional ingredients, but are designed to be very interesting, following trends and using marketing strategies. Unfortunately, many packaging products produced by diverse food producers local are not well managed and follow the rules and principles of business. For example, from a variety of packaging local still found products that have not included the composition of the product (ingredient), the weight of the contents of the packaging, No register (permission) from the Food and Drug Supervisory Agency (BPOM), Ministry of Health, Halal logo from Majelis Ulama Indonesia MUI), production date and expiration date. this condition indicates that the entrepreneur has not demonstrated the ability to apply business ethics from the perspective of consumer concern

The exclusion of various information on packaging products due to lack of knowledge and low awareness of the entrepreneurs about the application of business ethics or they already know but have not applied due to requirements and procedures. Besides, there is a factor of honesty that must be applied from the entrepreneur to provide actual information about the products they produce. This is a part of business ethics that must be known and understood and applied by entrepreneur as business actors. [1] Business Ethics has a complex meaning, the focus of this research is to see how the ethical application in doing food business is viewed from the ethics around the consumer with the concern of the entrepeneurs on the right of consumers to obtain healthy, safe and appropriate products when buying

Another factor that needs to be considered for growth is the competence factor of entrepreneur. Competence is a collection of science, skills and abilities, meaning that the 
knowledge possesses includes the main knowledge of the product process coupled with the support competencies such as communication, empathy, business ethics associated with consumer rights. Entrepreneurial competencies are seen as important to business growth and success, and, an understanding of the nature and role of such competencies can have important consequences for practice. However, despite the supposed importance of entrepreneurial competencies, the discussion of competencies in the entrepreneurial literature is in its early stages [2].

\section{LITERATURE REVIEW}

\section{A. Entrepreneur competencies}

Entrepreneurialcompetencieshave been investigated by many researchers, and the concept has been widely used in practice, but there is scope for considerably more theoretical and empirical work [2]. Competence is a concept that has many meanings and models of entrepreneurial competence based on various approaches and concepts of competency [3]. Competence is typically driven by aspirations to achieve superior performance, and the potential for, in turn, economic gain or business success [4]. Competencies are not readily available, but have to be developed or acquired during the early phases of their development. These initial phases concerning the processes of venture development, or organizational emergence [5].

Competence is seen as a description of something which a person who works in a given occupational area should be able to achieve, it is a description of an action, behaviour or outcome which a person should be able to demonstrate. [6]. According to [7] There are at least two key meanings or uses of the term competency: competency as behaviours that an individual demonstrates; and, competencies as minimum standards of performance. [8] suggests that competent behaviour results from a variety of factors including an individual's motivation, personality traits, self-concept, knowledge or skill and it is perhaps therefore not surprising that the boundaries and relationships between these terms are ill-defined. According to [9] there are ten element competencies such as knowing your business, Knowing the basic management, having the proper attitude, having adequate capital, Managing finances effectively, managing time efficiently, Managing people, Satisfying customer by providing high quality product, Knowing how to Compete, and copying with regulation and paper work.

\section{B. Business ethics}

Ethics defines as a person's situation-dependent application of moral standards, which stem from the traditions, values or beliefs that have grown in societies concerning right and wrong conduct [10]. Business ethics is a form of applied ethics that examines ethical principles and moral or ethical problems that arise in the business environment [11]. Business ethical issues reflects the degree to which business is perceived to be at odds with noneconomic social values [10]. Business ethics is both a normative and a descriptive discipline [12]. Business ethics has a very important role for companies to have high competitiveness and have the ability to create added value for the sustainability of business

According to [1] entrepreneur must have an ethical reflection. reflection ethics is ethical about what a businessman can do and should not be done to consumers. In other words the consumer must be treated morally well. Entrepreneur has a moral obligation to protect the consumer and avoid the occurrence of harm to consumers. There are 3 things that must be considered consumer Ethics of food Security, ethics of information and consumer ethics to be heard.

Ethics of food Security. Food products can contain risks such as preservatives or dyes that can harm the health of consumers. Entrepreneurs should pay attention such as healthy food, adequate nutrition. Food products produced should not harm the health or even endanger the lives of consumers. Ethics on the Right to Information. Consumers reserve the right to know all relevant information about the products they purchase, such as information labelling, ingredient, production permits, duration of use, halal label, information how to use / store, and risks that may be accompanied if any.Ethics for Listening. Consumers are entitled to convey various things about the product such as giving advice or complaining. For that the company must provide clear information on the packaging of its products. Such information can be in the form of telephone hotline (call center), email, social media and address to convey suggestions and complaints to the company.

\section{Business Growth}

Small businesses vary greatly in size and capacity for growth. They are characterized by independence of action, differing organizational structures, and diverse management styles. For entrepreneurs, understanding consumer behaviour and challengges business can aid them for survive and growth. several factors that need to be considered entrepreneur such as commitment, need for delegation and changes in their managerial roles, adaption in new technology (social media), business inovation, business ethics.

Successful business performance is evidenced by significant growth over time in equity capital. Such growth directly reflects increasing market and sales the accumulation of revenue, enhancement of solvency positions, expanded credit capacity, and strengthening of future income-generating capacity [13]. Based on the growth strategy, an entrepreneur must be able to maintain 
the level of operational efficiency and unrealized capital gain assets. The position of financial leverage can also affect growth through the dual effects of faster equity growth, coupled with a greater risk of financial loss.

[14] have identified eight factors for growth business in their research, of which four relate to the enterprise and four to the owner. (1). Financial resources (2) Personnel resources (3) Systems resources (4) Business resources (5) Owner's goals for himself or herself and for the business. (6) Owner's operational abilities in doing important jobs such as marketing, inventing, producing, and managing distribution. (7) Owner's managerial ability and willingness to delegate responsibility and to manage the activities of others (8) owner's strategic abilities for looking beyond the present and matching the strengths and weaknesses of the company with his or her goals.

[15] introduced business model canvas, a simple graphical template describing nine essential components in order to synchronize business activities: Customer segments, value propositions, channels, customer relationships, revenue streams, resources, activities, partnerships, and costs. The individual elements prompt consideration of a business' full scope, while the layout encourages thought about how the pieces fit together

\section{METHOD}

Research used questionnaire (quantitative research) in order tomeasure. The study questionnaire benefited from the [9] in regard tothe statements used in the competencies entrepreneur. Questionnaire of business ethics benefited from [1].Questionnaire of business growth benefited from [14] and [15]. Questionnaires were delivered to 66 respondents who have souvenir food business.

\section{Data screening and analysis}

This research is an associative research that explains the influence between variables and directed to the relationship model of variation orientation variable entrepreneur competencies, busienss ethics, and business growth. The study is located at Medan, Banda Aceh, Padang and Palembang city, with the object of entrepreneurs who have local food. This study used nonprobability sampling with a sample number of 66 entrepreneurs. The data collected were primary data from the questionnaires distributed in the sample using likert scale measurement, observation and interview with entrepreneurs. Secondary data from the literature and previous research for the needs of the study. Data processing begins with validity and reliability tests. Data analysis technique in this research using multiple regression analysis.

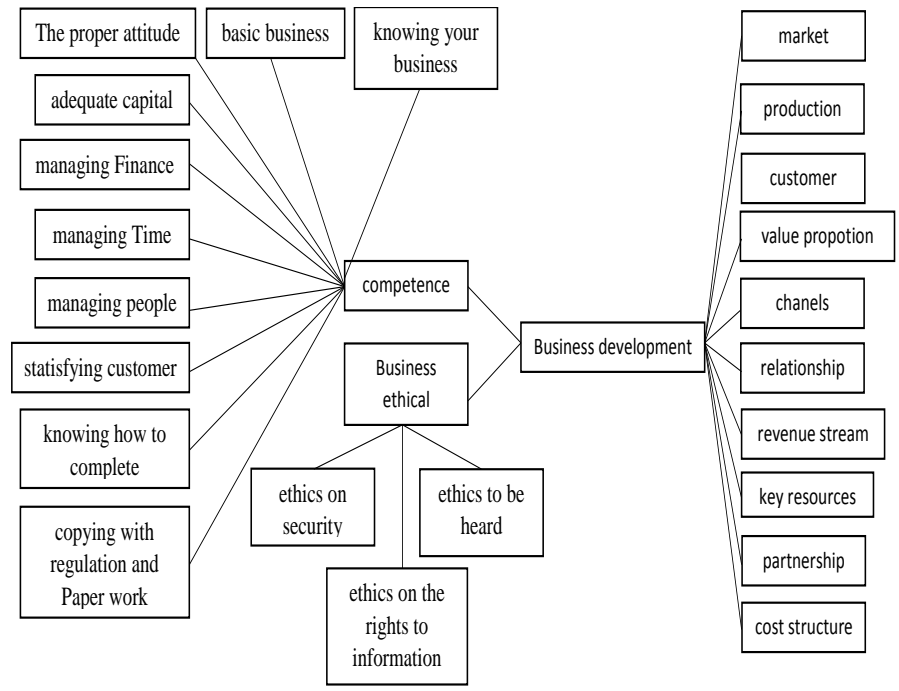

Figure 1 Conceptual framework

Result

Table 1. Descriptive

\begin{tabular}{|c|c|c|c|c|c|}
\hline \multicolumn{2}{|c|}{ Descriptive respondent } & \multirow{2}{*}{$\begin{array}{c}\text { Frequency } \\
9\end{array}$} & \multicolumn{2}{|c|}{$\begin{array}{l}\text { Deskriptive } \\
\text { respondent }\end{array}$} & \multirow{2}{*}{$\begin{array}{c}\text { Frequency } \\
36\end{array}$} \\
\hline \multirow{5}{*}{ Aged } & 23-33 years & & \multirow{2}{*}{$\begin{array}{l}\text { Using } \\
\text { social } \\
\text { media }\end{array}$} & Yes & \\
\hline & $34-43$ years & 14 & & No & 30 \\
\hline & $44-53$ years & 19 & \multirow{5}{*}{$\begin{array}{l}\text { Social } \\
\text { media } \\
\text { used }\end{array}$} & Facebook & 11 \\
\hline & $54-63$ years & 15 & & Instagram & 16 \\
\hline & $64-73$ years & 9 & & twitter & 2 \\
\hline \multirow{2}{*}{ Gender } & Male & 25 & & blog & 3 \\
\hline & Female & 41 & & whatsup & 3 \\
\hline \multirow{7}{*}{$\begin{array}{c}\text { How } \\
\text { long } \\
\text { doing a } \\
\text { business }\end{array}$} & $\begin{array}{c}\text { Under } 5 \\
\text { years }\end{array}$ & 13 & \multirow{5}{*}{$\begin{array}{l}\text { How } \\
\text { long } \\
\text { using } \\
\text { social } \\
\text { media }\end{array}$} & $\begin{array}{l}\text { Under } 6 \\
\text { months }\end{array}$ & 2 \\
\hline & $6-15$ years & 23 & & $\begin{array}{l}6 \text { months } \\
-1 \text { years }\end{array}$ & 8 \\
\hline & $16-25$ years & 15 & & $1-2$ years & 6 \\
\hline & $26-35$ years & 6 & & $2-3$ years & 11 \\
\hline & $36-45$ years & 2 & & $\begin{array}{ll}\text { Over } & 3 \\
\text { years } & \end{array}$ & 9 \\
\hline & $46-55$ years & 1 & \multirow{2}{*}{$\begin{array}{l}\text { Have a } \\
\text { website }\end{array}$} & Yes & 15 \\
\hline & $\begin{array}{c}\text { Over } 56 \\
\text { years }\end{array}$ & 6 & & No & 51 \\
\hline
\end{tabular}

According to table 1. Their business has been done for generations (over 5 years, there is 53 respondens. In the table of age, it can be seen that the respondents aged 44 years over, being dominant as many as 43 people $(65,15 \%)$, that implication they dont understand how to used social media. Only $(54,54 \%)$ using Social media and Instagram becomes a favorite of the respondent because of its ease to use, just by uploading the photo and describing it under the photo column. $77,27 \%$ responden do not use the website because they have difficulty using it. 
Table 2. Result

\begin{tabular}{|c|c|c|c|}
\hline From & To & $\begin{array}{c}\text { Standardized } \\
\text { Coefficients } \\
\text { Beta } \\
\end{array}$ & t Test \\
\hline Competence & \multirow{17}{*}{$\begin{array}{l}\text { Business } \\
\text { growth }\end{array}$} & & \\
\hline $\begin{array}{c}\mathrm{X}_{1} \text { sub knowing your } \\
\text { business }\end{array}$ & & ,225 & 2,546 \\
\hline $\mathrm{X}_{1}$ sub basic business & &, 130 & 1,717 \\
\hline $\mathrm{X}_{1}$ sub the proper attitude & & ,009 & ,107 \\
\hline $\mathrm{X}_{1}$ sub adequate capital & &,- 096 & $1, \overline{258}$ \\
\hline $\mathrm{X}_{1}$ sub managing finance & & ,076 & ,961 \\
\hline $\mathrm{X}_{1}$ sub managing time & &, 042 &, 543 \\
\hline $\mathrm{X}_{1}$ sub managing people & &, 150 & 2,107 \\
\hline $\begin{array}{c}\mathrm{X}_{1} \text { sub statisfying } \\
\text { customer }\end{array}$ & & 228 & 2,774 \\
\hline $\begin{array}{c}\mathrm{X}_{1} \text { sub knowing how to } \\
\text { compete }\end{array}$ & & ,322 & 4,176 \\
\hline $\begin{array}{l}\mathrm{X}_{1} \text { sub copying with } \\
\text { regulation and Paper } \\
\text { work } \\
\end{array}$ & &, 121 & 1,669 \\
\hline business ethics & & & \\
\hline $\mathrm{X}_{2}$ Subethics on security & & ,576 & 5,335 \\
\hline $\begin{array}{l}\mathrm{X}_{2} \text { Subethics on the rights } \\
\text { to informative }\end{array}$ & & ,059 & ,609 \\
\hline $\mathrm{X}_{2}$ Subethics to be heard & &, 120 & 1,111 \\
\hline Competence & & ,839 & 9,949 \\
\hline business ethics & &, 005 &, 064 \\
\hline
\end{tabular}

Table 2. Cont

\begin{tabular}{|c|c|c|c|}
\hline F test & sig & Adm-R ${ }^{2}$ & $\varepsilon$ \\
\hline 27,433 & ,000 & & \\
\hline & ,014 & \multirow{10}{*}{,803 } & \multirow{10}{*}{,197 } \\
\hline & ,092 & & \\
\hline & ,915 & & \\
\hline &, 214 & & \\
\hline & ,341 & & \\
\hline & ,589 & & \\
\hline & 040 & & \\
\hline & ,008 & & \\
\hline & 000 & & \\
\hline & ,101 & & \\
\hline \multirow[t]{6}{*}{14,825} & 000 & & \\
\hline & ,000 & \multirow{3}{*}{,390 } & \multirow{3}{*}{0,61} \\
\hline &, 545 & & \\
\hline & ,271 & & \\
\hline &, 000 & \multirow{2}{*}{,700 } & \multirow{2}{*}{,300 } \\
\hline & ,949 & & \\
\hline
\end{tabular}

Based on the table 2 it can be seen that entrepreneurial competencies has a positive and significant influence on the business growth. The dimension of entrepreneurial competencies that have a positive and significant influence such as knowing your business, managing people, satisfying customer, and knowing how to complete. Meanwhile the dimension of entrepreneurial competencies that not significant such as basic business, the proper attitude, adequate capital, managing finance, managing time and copying with regulation and paper work.

From result, it implies there is limitation of entrepreneur knowledge about finance and adequate capital. Based on research, entrepreneurs need knowledge and skills about financial literacy. this is in accordance with the surveyed of financial services authorities, the level of financial literacy of small entrepreneurs is still weak. the level of financial literacy of Indonesian people only amounted to $21.84 \%$ with a financial inclusion rate of $59.74 \%$. For small and medium enterprises (MSMEs), financial literacy rate of $15.68 \%$ with a financial inclusion rate of $53.34 \%$. to improve financial literacy requires access to banking and financial institutions for employers. Other findings, many entrepreneurs who have not used modern management in business.

Variable business ethics has a positive and significant effect on the business growth. The dimension of business ethics that have a positive and significant just the ethical security, meanwhile the dimension of business ethics that not significant is ethics on the rights to information and ethics to be heard. based on observations made on the packaging, many entrepreneurs have not posted product information such as food composition (ingredient), product expiration, date of manufacture, company address and hotline number or halal label. Many entrepreneurs who consider the information in the packaging product is not very important. They assume consumers are already sure with the products that they sell.

\section{CONCLUSION AND SUGGESTION}

The aim of this study was to analyzed the effect ofentrepreneurs competencies and business ethics to business growth on souvenir food. The results of the study are believed that entrepreneurs competencies and business ethics have positive significant to growth business. in order to compete, entrepreneurs should continue to improve their skills and expertise in the field of business management, especially matters relating to marketing strategy, market expansion, product innovation and financial Management.

The increasingly market competition, entrepreneurs are required to continuously improve their skills and knowledge in the field of business management. Innovation steps must be taken so that the company can keep growing and growing in accordance with market demand. Entrepreneurs must also take advantage of technological developments and social media. the growing middle class of Muslims in Indonesia makes them 
increasingly critical of the products offered, especially food products. Halal labels are of particular concern in making purchasing decisions. Indonesian Muslim consumers are viewed from the aspect of their preferences that not only seek functional or emotional value from a product or service, but also begin to care more and need to get spiritual benefits - a benefit related to how much distant products or services adhere to Islamic values. for that inclusion of halal label into one of the strategies in attracting consumer buying Intertest.

\section{References}

[1] Bertens, K. (2013). ETIKA, Yogyakarta: Kanisius

[2] Brinckmann, J. (2008), Competence of Top Management Teams and the Success of New Technology Based Firms: A Theoretical and Empirical Analysis Concerning Competencies of Entrepreneurial Teams and the Development of Their Ventures, Gabler Publishing, Wiesbaden.

[3] Mitchelmore, S and Rowley, J (2008) Entrepreneurial competencies: a literature review and development agenda, International Journal of Entrepreneurial Behaviour\& Research Vol. 16 No.2, 2010, pp. 92-111

[4] Spencer,M.Lyle and Spencer,M.Signe, 1993, Competence at Work:Models for Superrior Performance, John Wily \& Son,Inc,New York,USA

[5] Lichtenstein, B. M. B. and Brush, C. G. (2001). 'How do "resource bundles" develop and change in new ventures? A dynamic model and longitudinal exploration'. Entrepreneurship Theory and Practice, 25, Spring, 37-58

[6] Cheng, M.-I. and Dainty, A.R.J. (2003), "The differing faces of managerial competency in Britain and America", Journal of Management Development, Vol. 22 No. 6, pp. 527-37.

[7] Strebler, M., Robinson, D. and Heron, P. (1997), Getting the Best Out of Your Competencies, Institute of Employment Studies, University of Sussex, Brighton

[8] Hunt, J.M. (1998), "Toward the development of a competency model of family firm leadership", paper presented to the 12th Annual National Conference. United States Association for Small Business and Entrepreneurship, Clearwater, FL, 15-18 January.

[9] Triton PB., 2007, Entrepreneurship : Kiat Sukses Menjadi Pengusaha, Tugu Publisher, Yogyakarta

[10] Müller, R., Turner, R., Andersen, E. S., \& Shao, J. (2014). Ethics, Trust, and Governance in Temporary Organizations. PAPERS Project Management Journal, 45(4), 3954. https://doi.org/10.1002/pmj.21432

[11] Warren, R. C. (2011). Are we making progress in international business ethics? Humanomics, 27(3), 212224.

[12] Enderle, G., \& De George, R. T. (2014). Exploring and Conceptualizing International Business Ethics Introduction: A LifeLong Concern for International Affairs. https://doi.org/10.1007/s105510142182z
[13] Escalante, C.L. and Barry, P.J, (2002) "Business growth strategies of Illinois grain farms", Agricultural Finance Review, Vol. 62 Issue: 1, pp.69-79, https://doi.org/10.1108/00214890280001130

[14] Churchil, N.C. and Lewis, L.V (1983) The Five Stages of Small Business Growth, Harvard Business Review, retrive from : https://hbr.org/1983/05/the-five-stages-ofsmall-business-growth

[15] Ostewalder, Alexander and Pigneur, Yves. 2010. Business Model Generation. New Jersey: John Wiley \& Sons, Inc. 